\title{
Shared Mental Models and Inter-organizational AEC Project Teams
}

Faizan Shafique $^{1 *}$ and Sinem Mollaoglu-Scott ${ }^{2}$

\begin{abstract}
Shared Mental Models (SMM) is a well-established concept in cognitive psychology with strong links to team performance. Despite the extensive body of research in this area, the literature still presents varied perspectives and definitions for the SMM construct. Also, SMM empirical studies are limited to mostly the investigations of small disciplinary teams and are underutilized for inter-organizational project teams, such as those in the Architecture Engineering and Construction (AEC) industry. This study presents a detailed review of SMM literature resulting in a comprehensive framework and discusses the implications of SMM on AEC project teams, making a case for integrated project delivery. The study contributes to the body of knowledge by providing a theoretical lens of SMM through which to analyze the AEC literature related to project delivery processes.
\end{abstract}

\section{Keywords}

Shared Mental Models, AEC project teams, Project delivery characteristics

\footnotetext{
${ }^{1 *}$ School of Planning, Design and Construction, Michigan State University, East Lansing, Michigan, United States shafiqu2@msu.edu (Correponding author)

${ }^{2}$ School of Planning, Design and Construction, Michigan State University, East Lansing, Michigan, United States sinemm@msu.edu
} 


\section{Introduction}

Inter-organizational project teams involve actors from two or more distinct organizations working jointly to create a tangible product/service in a limited time period. In comparison to projects involving individuals from a single organization, they are much more complicated due to needs for higher level of coordination and interdependence across organizations for delivery of tasks (Jones and Lichtenstein, 2008). Architecture, Engineering and Construction (AEC) projects present a particularly challenging niche of inter-organizational project teams as they are fast-paced, location specific, and vary in size, type (eg, horizontal, vertical, new construction, renovation), systems, level of complexity, and risk (Forbes and Ahmed, 2011). Thus, sharing information effectively, and bringing all team members on board with uniform information is of immense importance in construction (Saram and Ahmed, 2001). This highlights the need to explore Shared Mental Models (SMM) literature in context of AEC.

Shared Mental Models (SMM) refer to the knowledge and its uniform understanding that team members share in an organized manner (CannonBowers et al., 1993; Klimoski and Mohammed, 1994). Extensive research has made SMM one of the most developed psychological concepts related to cognition (Mohammed et al., 2010). Since the very inception of the idea, it was hypothesized that SMM contribute positively towards team performance (Cannon-Bowers et al., 1993; Klimoski and Mohammed, 1994; Rouse et al., 1992), and a series of empirical evidence supported this claim (Edwards et al., 2006; Mathieu et al., 2000; Salas et al., 2005; Santos et al., 2015; Stout et al., 1999; Waller et al., 2004).

The goal of this study is to explore how SMM theory can be applied to improve AEC project delivery processes. To do so, the first objective of this study is to develop a comprehensive SMM framework. Despite extensive research, the literature shows variant views regarding the SMM construct. Most of the SMM research has preferred to collapse SMM knowledge into two major types: task and team related knowledge (Mohammed et al., 2010). However, there seems to be a lack of consensus on the components and contents of these
SMM categories. Additionally, new categories have recently emerged in the literature that are worth integrating into the original streamline of SMM research. Therefore, a comprehensive framework can bring much needed clarity in this area for future researchers and provide a theoretical lens through which to analyze the literature. The second objective of this study is to review the SMM framework areas in the light of AEC project teams. Project delivery methods for AEC projects play a pivotal role in defining the nature and extent of relationships between project stakeholders (Alarcón and Mesa, 2014); therefore, the third and final objective of this study is to make a case for integrated project delivery by discussing project delivery characteristics and their impact on SMM framework.

\section{Background}

The idea of SMM was proposed by Cannon-Bowers et al. (1990) in an effort to better understand and improve team performance and decision making. Rouse et al. (1992) stated three functions of SMM: 1) Description - allows team members to comprehend relevant information in a similar manner by clearly providing its purposes and forms; 2) Explanation delves into the details of procedures and results; and 3) Prediction - enables team members to anticipate the same outcomes and repercussions of specific actions. Figure 1 summarizes the nature of SMM based on Rouse et al. (1992). Cannon-Bowers et al. (1993) explain that teams perform more effectively when they share their understanding regarding the tasks, teams, equipment, rules, goals, and other aspects. Such shared understanding helps team members predict actions and behaviors of others, which becomes critical in constrained scenarios (eg, tight timelines, virtual teams) prohibiting in-depth communications and face-to-face interactions (Mathieu et al., 2000). In addition to similarity of mental models among team members, accuracy is also important and often overlooked (Edwards et al., 2006). Mathieu et al. (2005) refer to this concept as the quality of mental models, which includes both accuracy and completeness of information. The SMM construct has evolved since Rouse et al. (1992) presented the three types: 


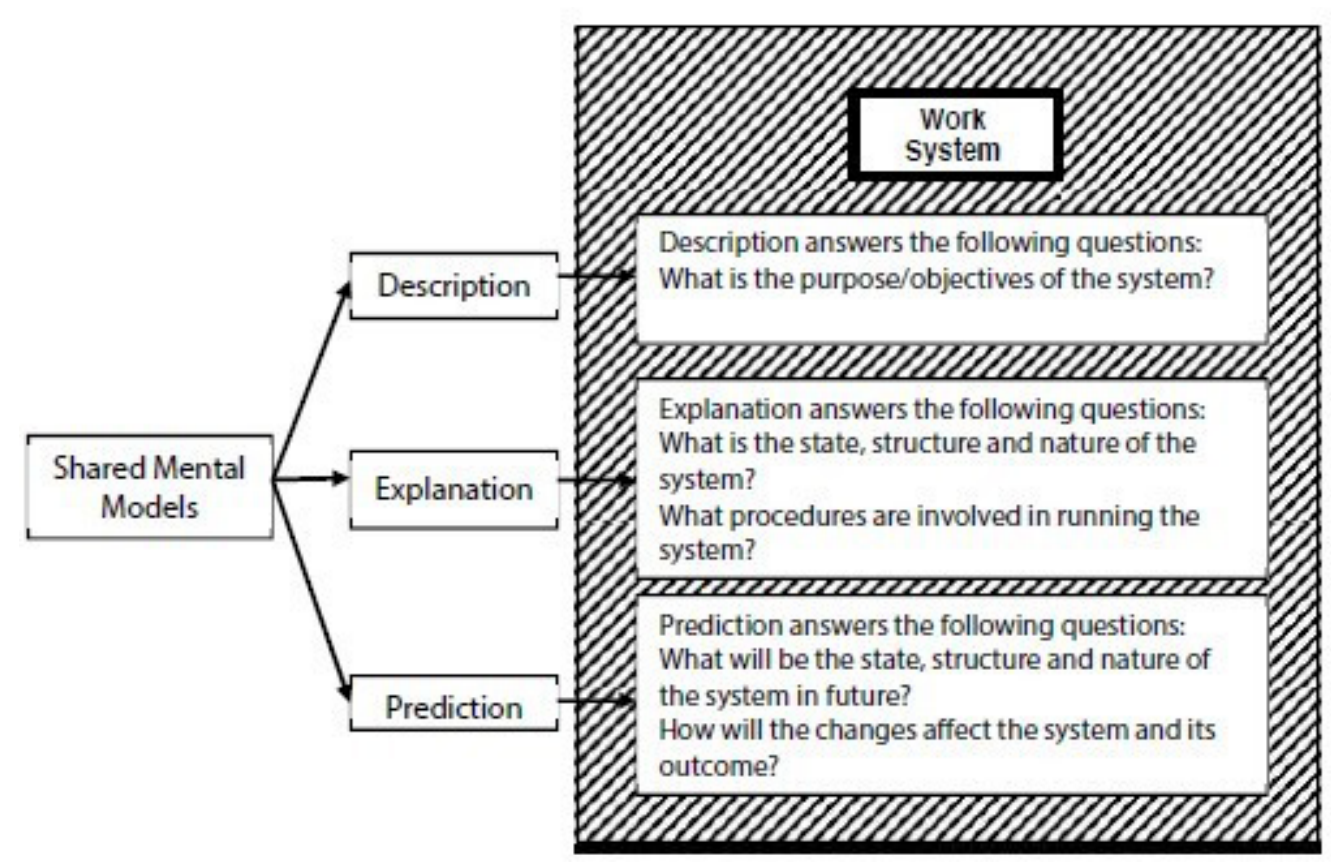

Figure 1 The functions of Shared Mental Models (Adopted from Rouse et al., 1992)

equipment knowledge, task knowledge, and team knowledge. Studies following the Rouse et al. (1992) study have proposed variants of these types (such as Mathieu et al., 2000; Standifer and Bluedorn, 2006). Multiple authors present varying perceptions regarding various SMM types. For instance, Rouse et al. (1992) divides SMM down to equipment, task, and team knowledge areas; whereas, Stout et al. (1993) divide SMM into declarative, procedural and strategic knowledge. Thus, there is an opportunity to synthesize the literature and bring much needed clarity to this area.

SMM is a well-established theoretical concept in the psychology domain (Mohammed et al., 2010), but when it comes to empirical evidence, there are only a handful of studies that investigate SMM for actual teams in industrial settings. Summarized in Table 1, these studies come from the construction ( Lingard et al., 2015), education (Johnson et al., 2011), engineering (Avnet and Weigel, 2013), information systems (Hsu et al., 2011), military (Graham et al., 2004), plant control (Waller et al., 2004), software development (Levesque et al., 2001), athletics (Blickensderfer et al., 2010), and business management (SmithJentsch et al., 2001) fields. Limitations exist in these investigations. First, the teams studied in these papers are small (ie, on average 5-6 member teams) and homogeneous (ie, members have similar expertise and come from the same organizations). A few studies did not even consider teams and measured similarity in perceptions of professionals in industry (such as Lingard et al., 2015; and Hsu et al., 2011). Consequently, these investigations failed to identify sub-teams (based on profession, background, organizational affiliation etc.), and thus investigate mental models at the unique setting of inter-organizational projects teams considering their multi-level nature. Second, the studies investigate similarity of only one or two knowledge components, such as shared knowledge of team members' responsibilities and estimates of others' workloads. Thus, these investigations also fall short in addressing a comprehensive scope of knowledge shared by team members that impacts the team performance. Because of these limitations, these studies fail to reach the full potential of SMM in their investigations.

Inter-organizational project teams involve actors from two or more distinct organizations working jointly to create a tangible product/service in a limited time period. In comparison to projects involving individuals from a single organization, 
Table 1 Empirical Shared Mental Models Studies from Various Industries and their Focus According to the SMM Framework

\begin{tabular}{|l|l|l|}
\hline $\begin{array}{l}\text { Industry/ } \\
\text { Source }\end{array}$ & Unit of analysis and sample & Variables \\
\hline $\begin{array}{l}\text { Construction / } \\
\text { Lingard et al., 2015 }\end{array}$ & $\begin{array}{l}\text { Individuals / 60 construction } \\
\text { professionals (ie, Architects, } \\
\text { Engineers, Contractors and Safety } \\
\text { professionals })\end{array}$ & $\begin{array}{l}\text { Perceptions of individuals for risks } \\
\text { and responses related to accidental } \\
\text { injuries }\end{array}$ \\
\hline $\begin{array}{l}\text { Education/ } \\
\text { Johnson et al., 2011 }\end{array}$ & $\begin{array}{l}\text { Perceptions regarding } \\
\text { communication, work environment, } \\
\text { and resources }\end{array}$ \\
\hline $\begin{array}{l}\text { Aeronautical Engineering/ } \\
\text { Avnet and Weigel (2013) }\end{array}$ & $\begin{array}{l}\text { A multi-disciplinary team / team of } \\
\text { customer representative }\end{array}$ & $\begin{array}{l}\text { Shared knowledge in engineering } \\
\text { design }\end{array}$ \\
\hline $\begin{array}{l}\text { Information Technology/ } \\
\text { Hsu et al., 2011 }\end{array}$ & Individuals / 134 project managers & $\begin{array}{l}\text { Shared understanding of team } \\
\text { members' responsibilities }\end{array}$ \\
\hline $\begin{array}{l}\text { Military / } \\
\text { Graham et al., 2004 }\end{array}$ & $\begin{array}{l}\text { Estimates of other team members' } \\
\text { workloads }\end{array}$ \\
\hline $\begin{array}{l}\text { Power plant control/ } \\
\text { Waller et al., 2004 }\end{array}$ & $\begin{array}{l}\text { Disciplinary teams/ 14 teams of 4-6 } \\
\text { nuclear power plant crew workers }\end{array}$ & $\begin{array}{l}\text { Understanding of the situations and } \\
\text { responses }\end{array}$ \\
\hline $\begin{array}{l}\text { Software development/ } \\
\text { Levesque et al., 2001 }\end{array}$ & $\begin{array}{l}\text { Disciplinary teams/ 62 teams of 5-6 } \\
\text { software developers }\end{array}$ & $\begin{array}{l}\text { Evaluation of communication } \\
\text { process, team climate and structure }\end{array}$ \\
\hline $\begin{array}{l}\text { Athletics / } \\
\text { Blickensderfer et al., 2010 }\end{array}$ & $\begin{array}{l}\text { Disciplinary teams/ 71 Pairs (2 person } \\
\text { teams) of tennis players }\end{array}$ & $\begin{array}{l}\text { Expectations regarding game } \\
\text { strategy }\end{array}$ \\
\hline
\end{tabular}

they are much more complicated due to needs for higher level of coordination and interdependence across organizations for delivery of tasks (Jones and Lichtenstein, 2008). AEC projects are unique and present additional challenges of fast pace, location, size, systems, and risks (Forbes and Ahmed, 2011). SMM literature has yet to explore interorganizational project team environments such as those in the AEC industry. To build the foundation for future research, the second goal of this study is to review the SMM framework areas in light of the AEC project team literature. The authors then further analyzed the potentials of SMM in this field by exploring the theoretical foundations for links with project delivery methods as one of the most prominent areas in the literature in analyzing AEC project delivery.

Project delivery methods for AEC projects play a pivotal role in defining the nature and extent of relationships between project stakeholders (Alarcón and Mesa, 2014). The most widely used delivery method still is the traditional, or
Design-Bid-Build (DBB), approach (Duggan and Patel, 2014; Konchar and Sanvido, 1998; Molenaar and Songer, 1998). In this approach, the owner initially hires a designer/engineer to prepare the bidding documents, including the design, specifications, and other required reports such as a geotechnical report or environmental assessment. Interested contractors then submit their proposals based on this bid package. The lowest bid gets selected for construction services. During construction, the designer has little communication with the constructor, and the communication is limited to answering the queries regarding design on behalf of the owner (CMAA (Construction Management Association of America), 2012). Such specialization and sequential nature of design and construction in DBB causes fragmentation of professionals from different disciplines, creating inefficiency, and lack of interoperability (Mollaoglu-Korkmaz et al., 2014). Realizing the significance of these issues, a new set of project delivery methods has emerged over time such 
as Construction Management-at-Risk (CM-atrisk), Design-Build (DB), and Integrative Project Delivery (IPD). These approaches aim at improving collaboration among project parties. Franz and Leicht (2016) categorized delivery methods based on (a) number of contracts held by the owner (ie, a single contract for both design and construction, such as in DB, versus DBB); (b) timing of contractor and subcontractors' involvement (ie, early involvement, such as in IPD, versus late involvement, such as in DBB); (c) prequalification of contractor and subcontractors; (d) selection criteria of contractor and sub-contractors (ie, low bid, qualification based, best value); and (e) terms of payment (ie, open book, lump sum, unit price).

\section{Methodology}

To explore how SMM theory can be applied to improve the project delivery processes, the authors first performed a detailed review of SMM literature, searching particularly for studies contributing towards SMM construct. The primary sources for this search were the following online search engines and databases: ProQuest, Web of Science, and Google Scholar. The authors used "shared mental models" and "team mental models" as keywords in this search which initially resulted in 156 publications including peer-reviewed journal papers and book chapters. These studies were carefully reviewed for new SMM knowledge. The majority of the publications adopted existing constructs and measures. Through careful review and elimination of works building on the existing SMM body of knowledge, the authors narrowed this pool of publications down to eight studies, and further analyzed those as presented in the next section.

The authors then developed a comprehensive SMM framework using past research, synthesizing SMM types presented in the literature to-date. The study revealed "knowledge area" as the common dimension in all constructs across studies (eg, equipment knowledge, task knowledge, potential situation knowledge); therefore, the authors built the SMM framework according to knowledge areas while ensuring that these areas are exhaustive and mutually exclusive (Bailey, 1994).

Next, the AEC literature was reviewed in the light of this SMM framework by using relevant key words for each framework area using the search engines listed above (eg, "Rules and Regulations in Construction", "Construction Procedures"). The articles were searched for the potential of SMM in improving AEC team and project performance. Finally, the authors further analyzed the potentials of SMM in this field via an in-depth review of a theoretical concept in AEC. Project delivery and its methods (eg, Design-Bid-Build [DBB], DesignBuild [DB]) is one of the most prominent areas in the literature to analyze AEC project delivery, teams, and performance outcomes. Through the lens of a recent study (Franz and Leicht, 2016) that classified project delivery methods, the authors explored the theoretical foundations for links between SMM and delivery methods in the AEC projects.

\section{Framework of Shared Mental Models}

The authors found eight key publications offering major contributions to SMM constructs originated from the organizational psychology and human resources domains (Table 2). They include three book chapters and five peer-reviewed articles. All references use knowledge area as basis for this categorization. Hence, knowledge area is the common dimension across all works.

SMM construct has evolved since Rouse et al. (1992) presented equipment knowledge, task knowledge, and team knowledge. Several researchers tried to redefine/expand SMM content but adopted, more or less, the same captions for categorization. However, there are two exceptions. First is Stout et al. (1993) that categorized shared knowledge in teams into declarative, procedural, and strategic mental models. Second is Standifer et al. (2006) that proposed a new SMM type related to time called temporal mental models. Both are discussed later in this section. Taking inspiration from these studies, we propose a SMM framework (Figure 2). We propose that overall SMM can be divided into three broad categories: task mental models and team mental models (as proposed by Mathieu et al., 2000) and the new category of 
Table 2 Shared Mental Model Constructs in the Literature

\begin{tabular}{|c|c|c|}
\hline Source & Constructs & Descriptions \\
\hline \multirow[b]{3}{*}{ Rouse et al. (1992) } & Equipment Knowledge & $\begin{array}{l}\text { Characteristics of equipment, functioning and } \\
\text { patterns }\end{array}$ \\
\hline & Task Knowledge & $\begin{array}{l}\text { Procedures, strategies and methodologies } \\
\text { required to perform tasks }\end{array}$ \\
\hline & Team Knowledge & $\begin{array}{l}\text { Roles of team members, relationships, and } \\
\text { temporal patterns they follow }\end{array}$ \\
\hline \multirow[b]{3}{*}{ Stout et al., 1993} & Declarative & Task goals, facts, rules, roles and positions. \\
\hline & Procedural & Task actions and goal relationships. \\
\hline & Strategic & Action plans, contextual analysis, contingencies . \\
\hline \multirow[b]{4}{*}{ Cannon-Bowers et al., 1993} & Equipment mental models & Tools and technology \\
\hline & Task Mental Models & Procedures, strategies and methodologies \\
\hline & $\begin{array}{l}\text { Team interaction mental } \\
\text { models }\end{array}$ & Roles, responsibilities, relationships and patterns \\
\hline & Team mental models & Skills, habits and behaviors \\
\hline \multirow[b]{2}{*}{$\begin{array}{l}\text { Mathieu et al., } 2000 \text { and } \\
\text { Cannon-Bowers et al., } 1993\end{array}$} & Task related mental models & $\begin{array}{l}\text { Combination of equipment and task mental } \\
\text { models }\end{array}$ \\
\hline & Team related mental models & $\begin{array}{l}\text { Combination of team interaction and team } \\
\text { mental models }\end{array}$ \\
\hline \multirow[b]{3}{*}{ Fiore et al., 2001} & Task knowledge & $\begin{array}{l}\text { Shared understanding of tasks being performed } \\
\text { by the team }\end{array}$ \\
\hline & Team knowledge & $\begin{array}{l}\text { Knowledge regarding individual responsibilities } \\
\text { and required actions }\end{array}$ \\
\hline & $\begin{array}{l}\text { Potential situation } \\
\text { knowledge }\end{array}$ & $\begin{array}{l}\text { Shared understanding of situations team may } \\
\text { encounter in future }\end{array}$ \\
\hline \multirow[b]{3}{*}{ Standifer and Bluedorn, 2006} & & $\begin{array}{l}\text { Knowledge about cycles (one complete } \\
\text { implementation) }\end{array}$ \\
\hline & & Knowledge about pace or speed of execution \\
\hline & Temporal mental models & $\begin{array}{l}\text { Knowledge about time orientation (interpretation } \\
\text { of time) }\end{array}$ \\
\hline \multirow[b]{3}{*}{ Johnson et al., 2007} & General Knowledge & $\begin{array}{l}\text { Knowledge that is not team or task dependent, } \\
\text { such as communication mediums }\end{array}$ \\
\hline & Task Knowledge & $\begin{array}{l}\text { Knowledge related to tasks. Depends on team } \\
\text { objectives }\end{array}$ \\
\hline & Team Knowledge & $\begin{array}{l}\text { Knowledge about skills and behaviors of other } \\
\text { team members }\end{array}$ \\
\hline \multirow[b]{3}{*}{ Santos et al., 2015} & Task dimension & $\begin{array}{l}\text { Shared understanding to objectives, information } \\
\text { and strategies }\end{array}$ \\
\hline & Team dimension & $\begin{array}{l}\text { Trust and mutual support amongst team } \\
\text { members }\end{array}$ \\
\hline & Time dimension & Shared understanding of time and planning \\
\hline
\end{tabular}




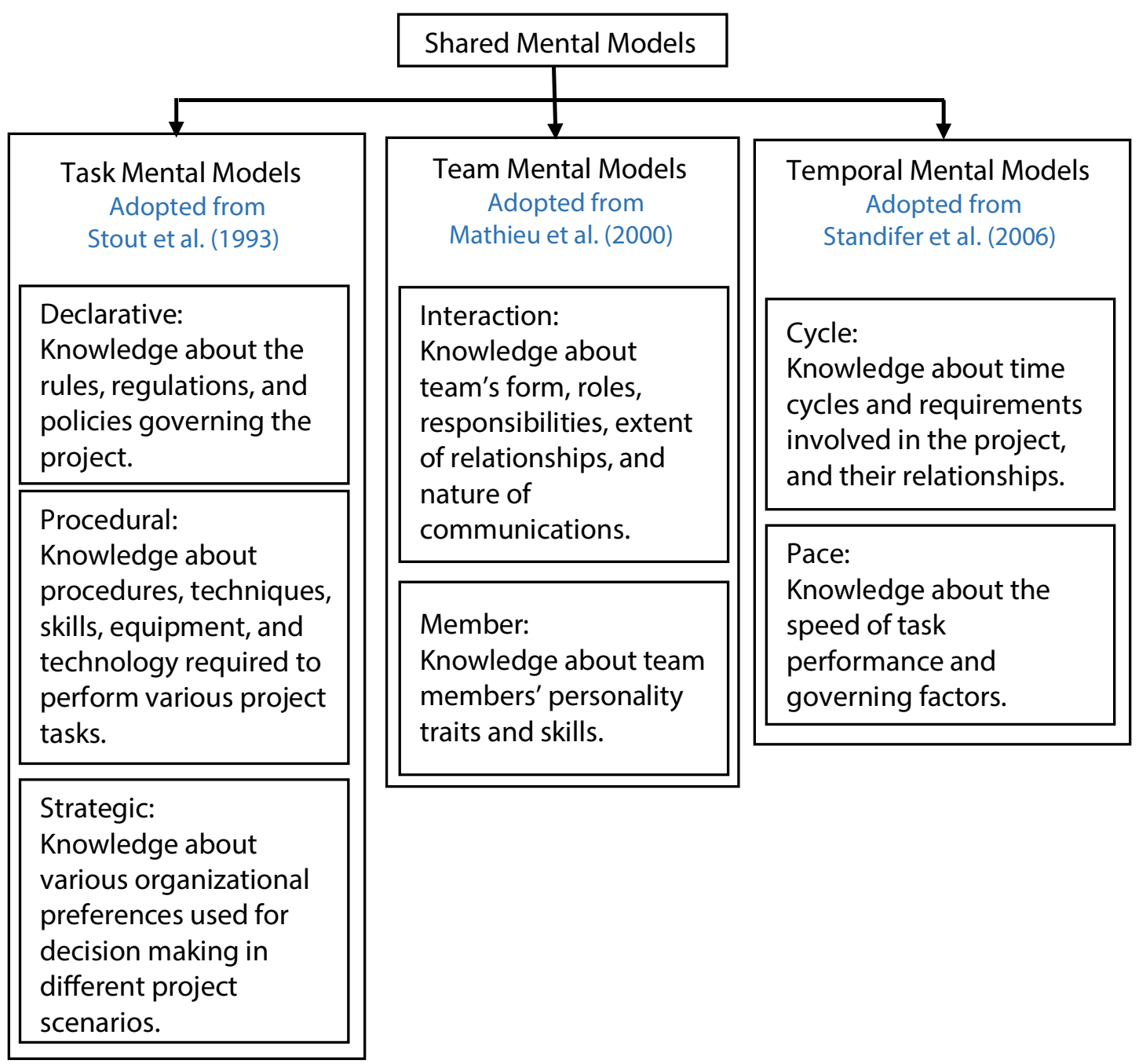

Figure 2 Shared Mental Models Framework.

temporal mental models (as proposed by Standifer and Bluedorn, 2006).

Task mental models cover all the task related knowledge including rules, regulations, procedures, machine skills, and the strategies to cope with various technical issues. Mathieu et al. (2000) proposed equipment/technology and task/ job mental models as sub-categories for task mental models. Both these divisions lack due to different reasons. equipment/technology mental models can't be generalized for all genres of teams and organizations, and task/job mental models is too broad a sub-category. In comparison, the subcategories proposed by Stout et al. (1993) -declarative, procedural and strategic mental models - are more detailed and generalizable; thus, we use them for our framework. Declarative mental models include all the knowledge related to rules, regulations, standards, and policies to be followed by teams. Declarative knowledge helps team members to understand what the work system looks like and the boundaries (Stout et al., 1993). Procedural mental models include knowledge of skills, procedures, techniques, equipment, and technology. Procedural knowledge helps the team members to understand how perform their respective tasks within the work system (Stout et al., 1993). Strategic mental models are the sharing of preferences among team members while making decisions in various scenarios. Strategic knowledge provides team members 
with the necessary introduction to context and organizational priorities (Stout et al., 1993).

Team mental models focus on the knowledge related to the team itself. Like Task Mental Models, Team Mental Models are also related to team performance (Mathieu et al., 2000). According to Mathieu et al. (2000), team related knowledge is divided into two main categories: interaction and member mental models. Interaction mental models cover the knowledge regarding the roles and responsibilities of team members, their interdependence, the nature of their interactions, and communication channels. They help team members to predict their communications and interactions with rest of the team (Mathieu et al., 2000). Member mental models are related to other team members' skills, attitudes, behaviors, orientations, and knowledge. (Mathieu et al., 2000). Communicating with and knowing your team members is a well-established team-building tool (Page and Donelan, 2003). They help team members in predicting behaviors, dealing with other teammates in the best suited manner, and providing appropriate information at the right time. Member Mental Models become important in case of flexible and dynamic work, as requirements, and expectations play a bigger role (Cannon-Bowers et al., 1993).

Temporal mental models Initially, time related knowledge was considered a part of task mental models, but many researchers have recently proposed to consider it as an independent third category (Santos et. al., 201; Mohammed et al., 2015) Standifer and Bluedorn (2006) proposed two main sub-categories for temporal mental models. Cycle mental models cover the knowledge about entrainment cycles existing inside the system. They help team members understand the patterns and flow of various activities. Pace mental models include the knowledge of speed of task performance, and the factors governing it. The perception of pace helps team members to accurately estimate the time required for the performance of activities (Standifer and Bluedorn, 2006).

\section{SMM and the AEC Industry}

As discussed previously, there is a need to investigate SMM in the context of inter-organizational project teams. Taking AEC project teams as a case here, the authors reviewed and presented the SMM framework areas in the light of AEC project teams literature in this section.

\section{Task Mental Models}

Declarative Mental Models: Some of the declarative mental model elements for AEC projects are company rules/regulations (eg, code of conduct, benefits, evaluation procedures, penalties for misconduct, flexibility of work hours), government regulations (eg, tort law, work permits, equipment permits, quota for minorities/women), and various standards/codes (eg, design, safety, construction, units of measurement). Declarative knowledge is important for AEC projects. Setting up rules for the project and making all team members aware of them creates team cohesion (Whatley, 2009). The regulations help in standard compliance and ensure performance (Baxendale and Jones, 2000). Also, one of the major causes of delay in construction projects is legal disputes between stakeholders (Assaf and Al-Hejji, 2006), and a similarity of understanding in this regard can help improve schedule performance.

Procedural Mental Models: AEC projects consist of many phases such as planning, schematic design, design development, and construction which require diverse procedural knowledge. For AEC projects, some elements of this knowledge are engineering and project management skills, correct interpretation of contracts, software skills required in design and construction, knowledge of standard operating procedures/project specifications, and knowledge regarding various dimensions of project performance (eg, cost, schedule, quality, safety, environment). Errors in construction and rework are common on construction projects and are known to cause delay and incur extra costs (Assaf and Al-Hejji, 2006). Skills shortage, incompetence, and lack of education regarding the procedural knowledge are key issues impeding performance on construction projects (ChangRichards et al., 2017; Lindhard and Larsen, 2016; Sawacha et al., 1999). The AEC literature has recommended standardizing the operating procedures in construction for better performance 
through similar and accurate understanding of procedural knowledge (Nakagawa, 2005).

Strategic Mental Models: Strategic knowledge in $A E C$ projects, includes the dynamics of construction project constraints (eg, economic, legal, environmental, technical, societal (Lau and Kong, 2006) and the organization's preferences regarding them. Typically, strategic decisions are based upon the organization's preferences for project dimensions like cost, schedule, quality, safety, and environment. Slow and/or incorrect decision making is categorized as one of the major causes of project delays in AEC (Chan and Kumaraswamy, 1997), which highlights the importance of strategic mental models in teams.

\section{Team Mental Models}

Interaction Mental Models: For effective team performance, it is important to clarify team member roles and responsibilities (Stout et al., 1999) which can be very complicated for AEC project teams. Labeling team member responsibilities is one of the major challenges, as AEC projects are interdisciplinary in nature, and a number of parties with diverse backgrounds are involved in the process (Hughes and Murdoch, 2001).

Member Mental Models: The ever-changing conditions and uncertainties in complex multi-team systems demand higher dependence on expectations from other team members (Cannon-Bowers et al., 1993). Member mental models become specifically important in such cases of flexible and dynamic work systems where AEC projects are prevalent. Member mental models can help team members in predicting behaviors, interacting with other team members in the best-suited manner, and providing appropriate information to the right person at the right time.

\section{Temporal Mental Models}

Cycle Mental Models: For AEC projects, cycle mental models include the information patterns of activities and schedules. It is very important for the team members to be on the same page of temporal sequencing. Knowing what comes first and the order of events helps team members to coordinate in a synchronized manner (Mohammed et al., 2015).

Pace Mental Models: Deadlines and milestones, which are of core importance for AEC project teams, are two of the major factors that influence the definition of pace for activities (Lindkvist et al., 1998). Time orientation, which defines how people in various cultures define, perceive, and measure time, is another key element of pace mental models (McGrath and Tschan, 2004; Standifer and Bluedorn, 2006).

\section{Making the Case for Integrated Project Delivery}

To highlight the potential of integrated forms of project delivery in development of SMM, characteristics by Franz and Leicht (2016) were used to analyze the potential impacts of delivery methods on SMM in AEC project teams. The summary of this analysis is presented in Table 3.

\section{Number of contracts held}

The literature indicates multiple implications that number of contracts held by a project team can have on SMM development. A single contract for design and construction ensures effective communication and better team integration (Bilbo et al., 2015; Mollaoglu-Korkmaz et al., 2013); thus, better knowledge sharing which leads to improved SMM in all framework areas: task, team, and temporal (Van \& de Ridder, 2004). Single contract reduces the size of project teams potentially contributing to improvement of SMM development (Mohammed et al., 2010). One party taking care of both design and construction also helps in cutting down the documentations and formalities, reducing the amount and complexity of declarative knowledge to be shared. Moreover, it improves team's strategic decision-making capacity and ensures a fast-track delivery (Chan, 2000). In such projects, design and construction personnel are usually associated with the same organization, which creates better working relationships due to already established member mental models (Chan, 2000). A single contract for design and construction is also empirically shown to ensure better and sustained pace of activities and, consequently, shorter project duration/cycles 
Table 3 Key Delivery Characteristics Defining Project Delivery Methods and their Potential Influence on AEC Project Team SMM

\begin{tabular}{|c|c|c|c|}
\hline \multirow{2}{*}{$\begin{array}{l}\text { SMM framework } \\
\text { areas }\end{array}$} & \multicolumn{3}{|c|}{ Impact of project delivery characteristics on SMMdevelopment } \\
\hline & Task mental models & Team mental models & Temporal mental models \\
\hline & \multicolumn{3}{|c|}{$\begin{array}{l}\text { A single contract for design and construction cut down on stakeholders leaving a smaller } \\
\text { project teams and consequently better SMM (Mohammed et al., 2010) }\end{array}$} \\
\hline & \multicolumn{3}{|c|}{$\begin{array}{l}\text { A single contract for design and construction facilitates integration and knowledge } \\
\text { sharing ( van den Hooff and de Ridder, 2004) potentially improving similarity of all } \\
\text { three types of mental models. }\end{array}$} \\
\hline $\begin{array}{l}\text { Number of contracts } \\
\text { held }\end{array}$ & $\begin{array}{l}\text { A single contract for } \\
\text { design and construction } \\
\text { helps in cutting down } \\
\text { the documentations and } \\
\text { formalities. This reduces } \\
\text { the amount and complexity } \\
\text { of declarative knowledge } \\
\text { to be shared (Chan, 2000), } \\
\text { assisting team's better } \\
\text { understanding of rules, } \\
\text { regulations and contractual } \\
\text { obligations. } \\
\end{array}$ & $\begin{array}{l}\text { A single contract for } \\
\text { design and construction } \\
\text { has a smaller number of } \\
\text { stakeholders involved and } \\
\text { already developed member } \\
\text { mental models in design } \\
\text { and construction personnel } \\
\text { (Chan, 2000). }\end{array}$ & $\begin{array}{l}\text { A single point of } \\
\text { responsibility allows } \\
\text { the team to have more } \\
\text { predictable standard cycles } \\
\text { and smoother pace of } \\
\text { activities (Hale et al., 2009), } \\
\text { increasing the similarity } \\
\text { and accuracy of Temporal } \\
\text { Mental Models. }\end{array}$ \\
\hline $\begin{array}{l}\text { Timing of } \\
\text { involvement }\end{array}$ & $\begin{array}{l}\text { Early involvement of key } \\
\text { stakeholders in the delivery } \\
\text { process matures the team's } \\
\text { understanding of rules, } \\
\text { regulations and strategic } \\
\text { constraints involved in } \\
\text { the project. Thus, the } \\
\text { team demonstrates better } \\
\text { regulation compliance and } \\
\text { makes better and informed } \\
\text { decisions } \\
\text { (Baxendale and Jones, } \\
\text { 2000; Forgues et al., 2012). }\end{array}$ & $\begin{array}{l}\text { Early involvement of } \\
\text { parties clarifies the roles } \\
\text { and responsibilities } \\
\text { of team members } \\
\text { (Mollaoglu-Korkmaz } \\
\text { et al., 2013). This helps } \\
\text { team members to predict } \\
\text { their communications and } \\
\text { interactions with rest of the } \\
\text { team (Mathieu et al., 2000). }\end{array}$ & $\begin{array}{l}\text { Bringing the contractor } \\
\text { early reduces RFI's/ } \\
\text { conflicts. This ensures } \\
\text { the speed of performance } \\
\text { is sustained with no } \\
\text { interruptions. (Mollaoglu- } \\
\text { Korkmaz et al., 2013). } \\
\text { Hence more predictability } \\
\text { through shared Cycle and } \\
\text { Pace Mental Models, and } \\
\text { better time performance. }\end{array}$ \\
\hline
\end{tabular}

Continued 
Table 3 Continued

\begin{tabular}{|c|c|c|c|}
\hline \multirow{2}{*}{$\begin{array}{l}\text { SMM framework } \\
\text { areas }\end{array}$} & \multicolumn{3}{|c|}{ Impact of project delivery characteristics on SMMdevelopment } \\
\hline & Task mental models & Team mental models & Temporal mental models \\
\hline $\begin{array}{l}\text { Selection criteria } \\
\text { for contractors and } \\
\text { subcontractors }\end{array}$ & $\begin{array}{l}\text { Qualifications-based and } \\
\text { best-value procurement } \\
\text { methods for contractor and } \\
\text { key subcontractor selection } \\
\text { ensures higher accuracy } \\
\text { in procedural mental } \\
\text { models (Alzahrani and } \\
\text { Emsley, 2013) where less } \\
\text { rework and higher quality } \\
\text { of workmanship can be } \\
\text { expected. }\end{array}$ & $\begin{array}{l}\text { Qualification based } \\
\text { selection ensures more } \\
\text { standard and professional } \\
\text { attitudes by the contractors } \\
\text { and subcontractors (Lo and } \\
\text { Yan, 2009). Thus, making } \\
\text { it easier for other parties to } \\
\text { predict their behavior. }\end{array}$ & $\begin{array}{l}\text { Qualification based } \\
\text { selection of contractors and } \\
\text { subcontractors makes sure } \\
\text { they are competent and well } \\
\text { versed with the industry } \\
\text { standard cycles and pace } \\
\text { of various construction } \\
\text { activities (Iyer and Jha, } \\
\text { 2006). Consequently, } \\
\text { competent contractors } \\
\text { ensure smooth and fact } \\
\text { execution (Lo and Yan, } \\
\text { 2009; Lo and Yan, 2009yer } \\
\text { \& Iyer and Jha, 2006). }\end{array}$ \\
\hline & \multicolumn{3}{|c|}{$\begin{array}{l}\text { Lack of transparency in payments adversely affect communication between owner and } \\
\text { builder ( Müller and Turner, 2005). Communication is the key to congruence of all three } \\
\text { types of SMM. }\end{array}$} \\
\hline Terms of Payment & & $\begin{array}{l}\text { Open book contracts } \\
\text { with transparent payment } \\
\text { structures help build } \\
\text { higher trust and better } \\
\text { understanding in teams } \\
\text { (Franz et al., 2016). }\end{array}$ & \\
\hline
\end{tabular}

(Hale et al., 2009). Elimination of contractual (and possibly organizational) boundaries between design and construction functions in a project helps facilitate a better feedback system via increased coordination and therefore, helps further refine mental models (Peña-Mora and Tamaki, 2001). Also, a design-builder has more flexibility to tailor the project cycles per team and owner expediting project delivery if and when needed by overlapping design and construction phases (Chan, 2000; Hale et al., 2009). One drawback of design-build delivery is that relationships within the bigger design-build party are not well defined (Peña-Mora and Tamaki, 2001) potentially leading to lack of goal alignment or team mental models. Integrated Project Delivery (IPD) is a multiparty agreement and overcomes this problem by ensuring all major stakeholders to be included in coordination and decision making ( Heidemann and Gehbauer, 2011). Thus, a more integrated approach, such as
IPD, can help reinforce the potentials of single contract.

\section{Timing of involvement}

Early involvement of key parties (ie, owners, designers, consultants, constructors, subcontractors and suppliers) ensures accurate understanding of declarative knowledge in teams, translating into better rules and regulations compliance (Baxendale and Jones, 2000). Additionally, when key parties are involved in the beginning of delivery process, it enables teams to make informed decisions due to better strategic awareness (Forgues et al., 2012). Such involvement can also help clarify member roles for all team members (interaction mental models) and develop shared project goals. Also, bringing stakeholders together early on in project delivery can help team members become familiar with each other, potentially helping to improve team relationships (Mollaoglu-Korkmaz et al., 
2013) via improved member mental models. The primary rule behind IPD is that all major parties are on-board from day one. One of the biggest advantages of doing so is drastic drops in claims and delays (Bilbo et al., 2015). Such smooth project execution can point to well developed temporal mental models.

\section{Selection criteria for contractors and sub- contractors}

Qualifications-based selection of contractors and subcontractors ensure competence and experience (Sawyer et al., 2015), which ensures that the selected party is already well-versed with the industry standards, legal obligations, and technical expertise required by the client, resulting in improved performance (Alzahrani and Emsley, 2013; Heidemann and Gehbauer, 2011). Thus, the team has well developed declarative and procedural mental models. Also, selections based on qualifications stimulates professionalism in parties which cultivates more predictable, positive, and standard behaviors as compared to the adversarial attitudes employed by traditional low-bid selection (Lo and Yan, 2009). This indicates towards the similarity and accuracy of team interaction and team member models. Integrated forms of project delivery are intrinsically qualification based and make sure the right parties with the right skills and the right attitude form the team (AIA National, 2007).

\section{Terms of payment}

Franz and Leicht (2016) reported transparency in terms of payment as one of major characteristics defining project delivery methods. It is reported that lack of transparency in payments (such as in lump sum contracts) adversely affects communication between owners and builders (Müller and Turner, 2005). Since communication is the key to SMM development (Mohammed et al., 2010), lack of transparency can negatively impact SMM similarity and accuracy. Open book contracts with transparent payments structures (such as guaranteed maximum price and cost plus fee) help build more trust and understanding in teams (Franz et al., 2016) leading to development of better team mental models. Integrated forms of project delivery, specially IPD, promote transparency in payments by involving everyone in target value design and setting bars for profit and loss sharing. As compared to traditional delivery methods, such as DBB, where participants' financial benefits are tied to individual performance, IPD ties payment of all parties to overall project success instead (AIA National, 2007). Hence, helping in aligning team goals or developing team interaction mental models.

The discussion above makes it clear that sharing of mental models in terms of both accuracy and similarity can be directly impacted by delivery method characteristics. The role of shared mental models in teams has already been acknowledged in improving team performance (Cannon-Bowers et al., 1993; Klimoski and Mohammed, 1994; Rouse et al., 1992). Consequently, the analysis presented above leads to the following proposition to be explored via future research: Key project delivery characteristics that differentiate delivery methods affect team performance mediated through shared mental models.

\section{Discussions}

This paper developed a comprehensive SMM framework with exhaustive and mutually exclusive areas. It can expand in the future as new mental model areas emerge, such as the 'belief structure' ( Mohammed et al., 2010). However, at this point, it is a complete representation with significant implications. Research, to date, is limited to a few knowledge elements. The presented SMM framework in this paper can enable researchers to approach this concept in a holistic manner. It is critical for team members to learn the "what" (task mental models), "how" (team mental models), and "when" (temporal mental models) of a system for optimum performance (Mohammed et al., 2015). Also, it is observed that teams might prefer a certain type of mental model and neglect others (Fransen et al., 2011). Holistic investigations can help compare and find the most significant SMM areas for any given team and present useful findings for practitioners. 
The paper also applied SMM in AEC teams considering the inter-organizational nature of projects. SMM development in AEC projects teams has many challenges. Communication and learning experiences are required for SMM to mature (Li et al., 2017). However, this process becomes challenging for AEC projects because of their inter-disciplinary and multi-level structures. In multi-level organizations, the inter-level perceptions of teamwork knowledge vary and might negatively affect performance outcomes (Clarke, 1999). One direction that this conundrum of SMM in inter-organizational project teams can be approached from is leadership. Effective leadership practices are credited to help create an environment of learning and sharing that catalyzes SMM development in teams ( $\mathrm{Li}$ et al., 2017). Addressing the interdisciplinary and multilevel knowledge variations, Blismas and Lingard (2006) recommended a cascading leadership strategy for managers to improve SMM across various levels of teams, which includes following elements: (a) act as role models; (b) have a clear understanding of the messages to be conveyed; (c) effectively communicate expectations, and (d) provide constant feedback. This strategy and other integrating leadership approaches can be explored for AEC project teams for mental model similarity. Team member characteristics, on the other hand, also show potential impacts on development of SMM. Studies show significant relationships of members' education (Rentsch and Klimoski, 2001), rank, experience (Smith-Jentsch et al., 2001), and mental abilities on similarity and accuracy of SMM. By replicating such studies for inter-organizational project teams such as AEC, valuable findings can be collected to assist recruitment, selection, and team development processes.

Lastly, this paper also established theoretical links between key project delivery characteristics that underline differences in delivery methods and SMMs in AEC project teams. The findings can be used in comparing different project delivery methods considered in the industry. It is observed that the traditional DBB might fall short in supporting the characteristics required for development of an optimal SMM, while integrated forms of contracts can be more facilitating in this regard. Empirical studies in this direction can help verify these theoretical deductions and develop a decision tool to design the best delivery method based on characteristics proposed by Franz and Leicht (2016). Research already provides evidence of integrated project teams (such as IPD) outperforming traditional DBB project teams (Hanna, 2016). This study proposes SMM as a mediator between the project delivery-team performance relationship. Thus, SMM can help not only explain this performance difference, but also optimize it.

In addition to those delivery methods discussed in this paper, non-contractual project delivery practices also exist in the AEC industry that can help facilitate the development of similar and accurate SMM among team members. The most common examples are Project Partnering, Lean Construction, and the use of Building Information Modeling (BIM). Project Partnering is a non-binding commitment between the parties of the project to set mutual goals and pursue them through joint governance and collaborative problem solving (Børve et al., 2017). Project Partnering ensures early goal alignment of key project parties and shared responsibility of outcomes through joint governance (Lahdenperä, 2012). Consequently, partnering improves team outputs such as greater commitment towards the project goals, open information sharing, and more frequent and effective communication between the parties (Sparkling et al., 2016), all leading towards improved SMM. Lean Construction, on the other hand, offers a number of different applications - such as Last Planner System (LPS) and Target Value Design (TVD) - aiming for improved value and reduced waste of time, effort, and resources in projects (Forbes and Ahmed, 2011) and encourages all parties to collectively define the project (Koskela et al., 2002). This ensures the alignment of purpose, goals, and strategies thus improving task and team SMM. LPS, proposed by the Lean Construction Institute, is an excellent technique that has great potential of improving temporal mental models. LPS plans the details of schedule close to the actual performance of work in a collaborative fashion (Forbes and Ahmed, 2011). This facilitates all parties to openly share their cycles and pace down 
to the units of days and hours. Use of BIM can also be considered as a factor that can potentially help improve SMM, especially related to a task. BIM can help team members visualize buildings components more effectively ( Azhar, 2011) potentially improving accuracy and similarity of procedural mental models. Additionally, there are multiple collaborative techniques being employed for innovation and goal alignment, such as design charrettes. Regular workshops, such as design charrettes can not only help develop shared goals in teams, but conducting them regularly also assist the team to remain aligned and focus. Thus, such collaborative sessions can have significant impact on team interaction model's accurate development and similarity.

\section{Conclusion}

SMM is a well-established, and highly regarded concept in the psychology of cognition that is underutilized in its true spirit, for complex systems such as inter-organizational project teams. This study aimed to explore the untapped potentials of SMM in the context of AEC projects: a representative case of inter-organizational project teams. The study put forth a new SMM framework, where three major types of SMM (namely task mental models, team mental models, and temporal mental models) are presented and explained based on the literature. The major contribution of this study to the body of knowledge is a theoretical lens of SMM through which to analyze the AEC literature related to project delivery processes.

Based on the findings presented in this study, a connection between AEC projects and SMM is successfully established, further making the case for integrated project delivery, paving the way for application of this renowned psychological concept as a tool for performance improvement. The types of knowledge to be shared among the team members in AEC projects are explicitly identified for each of the areas in proposed framework: task, team, and temporal. Managers and team leaders can use this for tracking the mental models of their teams. Also, trainings are designed for achieving SMM similarity and quality in teams for other areas (eg, Smith-Jentsch et al., 2008). Smith-Jentsch et al. (2008) reported that the participatory training styles were more effective in producing similarity of mental models and, consequently, team performance in Navy teams. Thus, mental models' similarity and accuracy is a measure of training effectiveness. As the holistic knowledge for SMM in AEC project teams is identified, comprehensive trainings and interventions for individuals and teams can be designed and applied.

This study was limited to review only key project delivery characteristics differentiating delivery methods and their potential links to SMM. The list of factors in AEC industry, that can potentially impact the SMM knowledge is comprehensive. It is important for future research to perform similar analyses with respect to other factors (eg, technology, cultural boundaries, and complexity of work) in the AEC industry that can potentially impact SMMs . The authors also realize the possibility of other psychological agents, working in parallel, and affecting the performance indications in the proposed studies. Therefore, an investigation into the psychological literature to identify such agents and incorporate their effect into the studies for reliable results is suggested.

With our findings, the authors aim to open new chapters of research and practice for interorganizational projects in general, and AEC projects in particular. SMM can be the answer to how team integration and cohesion relate to performance of teams and projects. With the knowledge categorized and defined, future research should focus on developing the tools to measure SMM in AEC inter-organizational project teams.

\section{References}

AIA National (2007), "Integrated project delivery: A guide", available at: http://info.aia.org/SiteObjects/ files/IPD_Guide_2007.pdf.

Alarcón, L.F. and Mesa, H.H. (2014), “A conceptual framework to model the performance of project delivery systems", eWork and eBusiness in Architecture, Engineering, pp. 603-608.

Alzahrani, J.I. and Emsley, M.W. (2013), “The impact of contractors' attributes on construction project success: A post construction evaluation", International Journal of Project Management, Vol. 31 No. 2, pp. 313-322.10.1016/j.ijproman.2012.06.006 
Assaf, S.A. and Al-Hejji, S. (2006), "Causes of delay in large construction projects", International Journal of Project Management, Vol. 24 No. 4, pp. 349357.10.1016/j.ijproman.2005.11.010

Avnet, M.S. and Weigel, A.L. (2013), "The structural approach to shared knowledge: An application to engineering design teams", Human factors, Vol. 55 No. 3, pp. 581-594.

Azhar, S. (2011), "Building information modeling (Bim): trends, benefits, risks, and challenges for the AEC industry", Leadership and Management in Engineering, Vol. 11 No. 3, pp. 241-252.

Bailey, K.D. (1994), Typologies and taxonomies: An introduction to classification techniques, Thousand Oaks, CA, Sage Publications, Inc.

Baxendale, T. and Jones, O. (2000), "Construction design and management safety regulations in practice - progress on implementation", International Journal of Project Management, Vol. 18 No. 1, pp. 33-40. 10.1016/S0263-7863(98)00066-0

Bilbo, D., Bigelow, B., Escamilla, E. and Lockwood, C. (2015), "Comparison of construction manager at risk and integrated project delivery performance on healthcare projects: a comparative case study", International Journal of Construction Education and Research, Vol. 11 No. 1, pp. 40-53. 10.1080/15578771.2013.872734

Blickensderfer, E.L., Reynolds, R., Salas, E. and Cannon-Bowers, J.A. (2010), "Shared expectations and implicit coordination in tennis doubles teams", Journal of Applied Sport Psychology, Vol. 22 No. 4, pp. 486-499. 10.1080/10413200.2010.507497

Blismas, N. and Lingard, H. (2006), "Building a safety culture: the importance of "shared mental models" in the Australian construction industry". In: Fang D, Chouldhry R, Hinze J, eds, Proceedings of CIB W99 International Conference on Global Unity for Safety and Health in Construction, Beijing, China, 28-30 June 2006. pp. 201-208.

Børve, S., Rolstadås, A., Andersen, B. and Aarseth, W. (2017), "Defining project partnering", International Journal of Managing Projects in Business, Vol. 10 No. 4, pp. 666-699. 10.1108/IJMPB-10-2016-0076

Cannon-Bowers, J., Salas, E. and Converse, S. (1993), "Shared mental models in expert team decision making”. In: Castellan N. J Jr, ed, "Individual and group decision making: Current issues”. Hillsdale, NJ, Lawrence Erlbaum Associates, Inc, pp. 221-246.

Cannon-Bowers, J.A., Salas, E. and Converse, S.A. (1990), "Cognitive psychology and team training:
Shared mental models in complex systems", Human Factors Bulletin, Vol. 33, pp. 1-4.

Chan, A.P.C. (2000), "Evaluation of enhanced design and build system a case study of a hospital project", Construction Management and Economics, Vol. 18 No. 7, pp. 863-871. 10.1080/014461900433140

Chan, D.W.M. and Kumaraswamy, M.M. (1997), “A comparative study of causes of time overruns in Hong Kong construction projects", International Journal of Project Management, Vol. 15 No. 1, pp. 55-63. 10.1016/S0263-7863(96)00039-7

Chang-Richards, Y., Wilkinson, S., Seville, E. and Brunsdon, D. (2017), "Effects of a major disaster on skills shortages in the construction industry", Engineering, Construction and Architectural Management, Vol. 24 No. 1, pp. 2-20. 10.1108/ECAM03-2014-0044

Clarke, S. (1999), "Perceptions of organizational safety: implications for the development of safety culture", Journal of Organizational Behavior, Vol. 20 No. 2, pp. 185-198. 10.1002/ (SICI)1099-1379(199903)20:2<185::AIDJOB892>3.0.CO;2-C

CMAA (Construction Management Association of America) (2012), “An Owners' Guide To Project Delivery Methods", available at: https://cmaanet.org [5/10/2018].

Duggan, T. and Patel, D. (2014), "Design-build project delivery market share and market size report", $R C D /$ RS Means Market Intelligence Confidential Rep. for $D B I A$, Norwell, MA, Reed Construction Data.

Edwards, B.D., Day, E.A., Arthur, W. and Bell, S.T. (2006), "Relationships among team ability composition, team mental models, and team performance", Journal of Applied Psychology, Vol. 91 No. 3, pp. 727-736. 10.1037/0021-9010.91.3.727

Fiore, S.M., Salas, E. and Cannon-Bowers, J. (2001), "Group dynamics and shared mental model development". In: London M, ed, "How people evaluate others in organizations". Mahwah, NJ, Lawrence Erlbaum Associates Publishers, pp. 309-336.

Forbes, L.H. and Ahmed, S.M. (2011), “Modern construction; lean project delivery and integrated practices", Boca Raton, FL, CRC Press.

Forgues, D., Iordanova, I., Valdivesio, F. and StaubFrench, S. (2012), "Rethinking the Cost Estimating Process through 5D BIM: A Case Study", Construction Research Congress 2012, West Lafayette, Indiana, May 21-23, 2012. Reston, VA: ASCE.

Fransen, J., Kirschner, P.A. and Erkens, G. (2011), "Mediating team effectiveness in the context of collaborative learning: the importance of team and task

Engineering Project Organization Journal

(C) 2020 Engineering Project Organization Society www.epossociety.org 
awareness", Computers in Human Behavior, Vol. 27 No. 3, pp. 1103-1113.10.1016/j.chb.2010.05.017

Franz, B., Leicht, R., Molenaar, K. and Messner, J. (2016), "Impact of Team Integration and Group Cohesion on Project Delivery Performance", Journal of Construction Engineering and Management, Vol. 143 No. 1, pp. 1-12.

Franz, B.W. and Leicht, R.M. (2016), “An alternative classification of project delivery methods used in the United States building construction industry", Construction Management and Economics, Vol. 34 No. 3, pp. 160-173. 10.1080/01446193.2016.1183800

Graham, J., Schneider, M., Bauer, A., Bessiere, K. and Gonzalez, C. (2004), "Shared mental models in military command and control organizations: effect of social network distance", Proceedings of the Human Factors and Ergonomics Society Annual Meeting, Vol. 48 No. 3, pp. 509-512. 10.1177/154193120404800350

Hale, D.R., Shrestha, P.P., Gibson, G.E. and Migliaccio, G.C. (2009), "Empirical comparison of Design/Build and Design/Bid/Build project delivery methods", Journal of Construction Engineering and Management, Vol. 135 No. 7, pp. 579-587. 10.1061/ (ASCE)CO.1943-7862.0000017

Hanna, A.S. (2016), "Benchmark performance metrics for integrated project delivery", Journal of Construction Engineering and Management, Vol. 142 No. 9, p. 04016040. 10.1061/(ASCE)CO.19437862.0001151

Heidemann, A. and Gehbauer, F. (2011), "The way towards cooperative project delivery", Journal of Financial Management of Property and Construction, Vol. 16 No. 1, pp. 19-30.

Hsu, J.S., Liang, T.P., Wu, S.P.J., Klein, G. and Jiang, J.J. (2011), "Promoting the integration of users and developers to achieve a collective mind through the screening of information system projects", International Journal of Project Management, Vol. 29 No. 5, pp. 514-524. 10.1016/j.ijproman.2010.06.006

Hughes, W. and Murdoch, J.R. (2001), Roles in construction projects: analysis and terminology, Birmingham, Construction Industry Publications.

Iyer, K.C. and Jha, K.N. (2006), "Critical factors affecting schedule performance: evidence from Indian construction projects", Journal of Construction Engineering and Management, Vol. 132 No. 8, pp. 871-881. 10.1061/(ASCE)07339364(2006)132:8(871)

Johnson, T.E., Lee, Y., Lee, M., O'Connor, D.L., Khalil, M.K. and Huang, X. (2007), "Measuring Sharedness of Team-Related knowledge: design and validation of a shared mental model instrument", Human
Resource Development International, Vol. 10 No. 4, pp. 437-454. 10.1080/13678860701723802

Johnson, T.E., Top, E. and Yukselturk, E. (2011), "Team shared mental model as a contributing factor to team performance and students' course satisfaction in blended courses", Computers in Human Behavior, Vol. 27 No. 6, pp. 2330-2338. 10.1016/j. chb.2011.07.012

Jones, C. and Lichtenstein, B.B. (2008), “Temporary inter-organizational projects: how temporal and social embeddedness enhance coordination and manage uncertainty". In: Cropper S, Ebers M, Huxham C, Smith Ring P, eds, The Oxford Handbook of Inter-Organizational Relations. Oxford, UK, Oxford University Press, pp. 231-255.

Klimoski, R. and Mohammed, S. (1994), "Team mental model: construct or metaphor?" Journal of Management, Vol. 20 No. 2, pp. 403-437. $10.1177 / 014920639402000206$

Konchar, M. and Sanvido, V. (1998), "Comparison of U.S. project delivery systems”, Journal of Construction Engineering and Management, Vol. 124 No. 6, pp. No. 435-444. 10.1061/(ASCE)07339364(1998)124:6(435)

Koskela, L., Howell, G., Ballard, G. and Tommelein, I. (2002), "The Foundations of Lean Construction". In: Valence de, ed, Design and Construction: Building in Value, Oxford, UK, Butterworth Heinemann, pp. 211-226.

Lahdenperä, P. (2012), "Making sense of the multiparty contractual arrangements of project partnering, project alliancing and integrated project delivery", Construction Management and Economics, Vol. 30 No. 1, pp. 57-79. 10.1080/01446193.2011.648947

Lau, E. and Kong, J. (2006), "Identification of constraints in construction projects to improve performance". Proceedings of the Joint Conference on Construction, Culture, Innovation and Management, Dubai, November 26-29", pp. 655-663.

Levesque, L.L., Wilson, J.M. and Wholey, D.R. (2001), "Cognitive divergence and shared mental models in software development project teams", Journal of Organizational Behavior, Vol. 22 No. 2, pp. 135-144. 10.1002/job.87

Li, M., Zhang, P., Xia, Y. and Liu, W. (2017), "Shaping the shared mental model: How leader humility helps teams to learn", Journal of Management and Organization, pp. 1-19.

Lindhard, S. and Larsen, J.K. (2016), "Identifying the key process factors affecting project performance", Engineering, Construction and Architectural Management, Vol. 23 No. 5, pp. 657-673. 10.1108/ ECAM-08-2015-0123

Engineering Project Organization Journal

(C) 2020 Engineering Project Organization Society

www.epossociety.org 
Lindkvist, L., Soderlund, J. and Tell, F. (1998), "Managing product development projects: on the significance of Fountains and deadlines", Organization Studies, Vol. 19 No. 6, pp. 931-951. 10.1177/017084069801900602

Lingard, H., Peihua Zhang, R., Blismas, N., Wakefield, R. and Kleiner, B. (2015), "Are we on the same page? Exploring construction professionals' mental models of occupational health and safety", Construction Management and Economics, Vol. 33 No. 1, pp. 73-84.

Lo, W. and Yan, M.-R. (2009), "Evaluating Qualification-Based selection system: a simulation approach", Journal of Construction Engineering and Management, Vol. 135 No. 6, pp. 458-465. 10.1061/(ASCE)CO.1943-7862.0000013

Mathieu, J.E., Heffner, T.S., Goodwin, G.F., CannonBowers, J.A. and Salas, E. (2005), "Scaling the quality of teammates' mental models: equifinality and normative comparisons", Journal of Organizational Behavior, Vol. 26 No. 1, pp. 37-56. 10.1002/ job.296

McGrath, J.E. and Tschan, F. (2004), Temporal matters in social psychology: Examining the role of time in the lives of groups and individuals, Washington, DC, American Psychological Association.

Mathieu, J.E., Heffner, T.S., Goodwin, G.F., Salas, E. and Cannon-Bowers, J.A. (2000), "The influence of shared mental models on team process and performance", Journal of Applied Psychology, Vol. 85 No. 2, pp. 273-283. 10.1037/0021-9010.85.2.273

Mohammed, S., Ferzandi, L. and Hamilton, K. (2010), "Metaphor no more: a 15-year review of the team mental model construct", Journal of Management, Vol. 36 No. 4, pp. 876-910. 10.1177/0149206309356804

Mohammed, S., Hamilton, K., Tesler, R., Mancuso, V. and McNeese, M. (2015), "Time for temporal team mental models: Expanding beyond "what" and "how" to incorporate "when", European Journal of Work and Organizational Psychology, Vol. 24 No. 5, pp. 693-709. 10.1080/1359432X.2015.1024664

Molenaar, K.R. and Songer, A.D. (1998), "Model for public sector Design-Build project selection", Journal of Construction Engineering and Management, Vol. 124 No. 6, pp. 467-479. 10.1061/(ASCE)07339364(1998)124:6(467)

Mollaoglu-Korkmaz, S., Miller, V.D. and Sun, W. (2014), "Assessing key dimensions to effective innovation implementation in interorganizational project teams: an integrated project delivery case",
Engineering Project Organization Journal, Vol. 4 No. 1, pp. 17-30. 10.1080/21573727.2013.855895

Mollaoglu-Korkmaz, S., Swarup, L. and Riley, D. (2013), "Delivering sustainable, high-performance buildings: influence of project delivery methods on integration and project outcomes", Journal of Management in Engineering, Vol. 29 No. 1, pp. 71-78. 10.1061/(ASCE)ME.1943-5479.0000114

Müller, R. and Turner, J.R. (2005), “The impact of principal-agent relationship and contract type on communication between project owner and manager", International Journal of Project Management, Vol. 23 No. 5, pp. 398-403.

Nakagawa, Y. (2005), Importance of Standard Operating Procedure Documents and Visualization to Implement Lean Construction", 13th International Group for Lean Construction Conference, Sydney, 2005, Sydney, International Group on Lean Construction.

Page, D. and Donelan, J.G. (2003), “TeamBuilding tools for students", Journal of Education for Business, Vol. 78 No. 3, pp. 125-128. 10.1080/08832320309599708

Peña-Mora, F. and Tamaki, T. (2001), "Effect of delivery systems on collaborative negotiations for largescale infrastructure projects", Journal of Management in Engineering, Vol. 17 No. 2, pp. 105-121. 10.1061/(ASCE)0742-597X(2001)17:2(105)

Rentsch, J.R. and Klimoski, R.J. (2001), "Why do ?great minds? think alike?: antecedents of team member schema agreement", Journal of Organizational Behavior, Vol. 22 No. 2, pp. 107-120. 10.1002/job.81

van den Hooff, B. and de Ridder, J.A. (2004), "Knowledge sharing in context: the influence of organizational commitment, communication climate and CMC use on knowledge sharing", Journal of Knowledge Management, Vol. 8 No. 6 117-130.

Rouse, W.B., Cannon-Bowers, J. and Salas, E. (1992), "The role of mental models in team performance in complex systems", IEEE Transactions on Systems, Man”, \& Cybernetics, Vol. 22 No. 6, pp. 12961308.

Salas, E., Sims, D.E. and Burke, C.S. (2005), "Is there a "Big Five" in Teamwork?" Small Group Research, Vol. 36 No. 5, pp. 555-599. $10.1177 / 1046496405277134$

Santos, C.M., Uitdewilligen, S. and Passos, A.M. (2015), "A temporal common ground for learning: the Moderating effect of shared mental models on the relation between team learning behaviours and performance improvement", European Journal of

Engineering Project Organization Journal

(C) 2020 Engineering Project Organization Society www.epossociety.org 
Work and Organizational Psychology, Vol. 24 No. 5, pp. 710-725. 10.1080/1359432X.2015.1049158

Saram, D.Dde. and Ahmed, S.M. (2001), "Construction coordination activities: what is important and what consumes time", Journal of Management in Engineering, Vol. 17 No. 4, pp. 202-213. 10.1061/ (ASCE)0742-597X(2001)17:4(202)

Sawacha, E., Naoum, S. and Fong, D. (1999), "Factors affecting safety performance on construction sites", International Journal of Project Management, Vol. 17 No. 5, pp. 309-315. 10.1016/S02637863(98)00042-8

Sawyer, J.T., Brian, M.S., Perrenoud, A.J., Smithwick, J.B. and Sullivan, K.T. (2015), "QualificationsBased Selection of Construction Services: Evaluation Criteria That Best Differentiate Contractor Qualifications", Paper presented in the 51st ASC Annual International Conference, Texas A \& M. Fort Collins, CO: Associated Schools of Construction.

Smith-Jentsch, K., Cannon-Bowers, J., Tannenbaum, S. I. and Salas, E. (2008), "Guided team selfcorrection: Impacts on team mental models, processes, and effectiveness", Small Group Research, Vol. 39 No. 3, pp. No. 303-327.

Smith-Jentsch, K.A., Campbell, G.E., Milanovich, D.M. and Reynolds, A.M. (2001), "Measuring teamwork mental models to support training needs assessment, development, and evaluation: two empirical studies", Journal of Organizational Behavior, Vol. 22 No. 2, pp. 179-194. 10.1002/job.88
Sparkling, A.E., Mollaoglu, S. and Kirca, A. (2016), "Research Synthesis Connecting Trends in Architecture, Engineering, and Construction Project Partnering", Journal of Management in Engineering, Vol. 4016033 No. 1, pp. 1-12.

Standifer, R. and Bluedorn, A. (2006), “Alliance management teams and entrainment: sharing temporal mental models", Human Relations, Vol. 59 No. 7 , pp. 903-927. 10.1177/0018726706067596

Stout, R.J., Cannon-Bowers, J.A. and Salas, E. (1993), "The role of shared mental models in developing shared situational awareness". In: Gilson R, Garland D, Koonce J, eds, Situational awareness in complex systems. Daytona Beach, FL, Embry-Riddle Aeronautical University Press, pp. 297-304.

Stout, R.J., Cannon-Bowers, J.A., Salas, E. and Milanovich, D.M. (1999), "Planning, shared mental models, and coordinated performance: an empirical link is established", Human Factors: The Journal of the Human Factors and Ergonomics Society, Vol. 41 No. 1, pp. 61-71. 10.1518/001872099779577273

Waller, M.J., Gupta, N. and Giambatista, R.C. (2004), "Effects of adaptive behaviors and shared mental models on control Crew performance", Management Science, Vol. 50 No. 11, pp. 1534-1544. 10.1287/ mnsc. 1040.0210

Whatley, J. (2009), "Ground rules in team projects: findings from a prototype system to support students", Journal of Information Technology Education: Research, Vol. 8, pp. 161-176.10.28945/165 